\title{
Effects of Type 2 Diabetes Mellitus Induction and of Moderate Physical Exercise on the Hepatic Metabolism and Oxidative Stress in Wistar Rats
}

\author{
Denise Silva de Oliveira ${ }^{1}$, Júlia Matzenbacher dos Santos², Kayorrany Gomes Galvão do Prado ${ }^{1}$ \\ Andreia Vitor Couto Amaral ${ }^{1}$, Sandra Aparecida Benite-Ribeiro³
}

\begin{abstract}
Aims: The aim of the study was to verify if the induction of Type 2 Diabetes Mellitus (T2DM) by the association of streptozotocin and high fat diet causes hepatic alterations and if physical exercise can influence these alterations. Methods: 46 males Wistar rats were divided into two groups: A high fat group (HF) that received a diet containing $60 \%$ of fat for 8 weeks and on the $14^{\text {th }}$ received a single dose of streptozotocin $(25 \mathrm{mg} / \mathrm{kg})$; a control group (C) that received a standard diet and a single dose of citrate buffer. Animals were them divided into two subgroups: one sedentary (S) and the other submitted to physical exercise (PE), totalizing four groups: C-S; C-PE; HF-S; HF-PE. Body weight and capillary glucose were measured weekly. After euthanasia hepatic concentrations of triacylglycerol (TAG), very low-density lipoprotein (VLDL); alanine transaminase (ALT), aspartate transaminase (AST), arginase; plasma concentration of glucose, urea, and 8-isoprostane (an oxidative stress marker) were measured. Results: Capillary glucose was higher in HF-S and HF-PE compared to C-S and C-PE groups. There were no differences in ALT, AST, arginase, oxidative stress concentration among the groups. Urea concentration was lower in HF-S and HF-PE than in C-PE. Liver TAG and VLDL were higher in the HF-PE group when compared to the C-S. Conclusions: The used protocol induced T2DM but not liver diseases or increase in blood oxidative stress. Besides, PE acted in synergy with high fat diet and STZ inducing accumulation of TAG and VLDL in hepatic tissue, an effect that could either represents lipotoxicity or a protective mechanism to conserve energy.
\end{abstract}

Descriptors: Amino acid metabolism. High fat diet. Insulin resistance. Triacylglycerol.

EFEITOS DA INDUÇÃO DO DIABETES MELLITUS TIPO 2 E DO EXERCÍCIO FÍSICO MODERADO NO METABOLISMO HEPÁTICO E NO ESTRESSE OXIDATIVO EM RATOS WISTAR

RESUMO

Objetivos: O objetivo deste estudo foi verificar se a indução de Diabetes Mellitus tipo 2 (T2DM) com baixa dose de estreptozotocina e dieta hiperlipídica causa alteraç̃̃es hepáticas e estresse oxidativo e o efeito do exercício físico nessas alterações. Métodos: 46 ratos Wistar machos foram divididos em dois grupos. Um recebeu uma dieta contendo $60 \%$ de gordura por 8 semanas e no 140 dia receberam uma dose única de estreptozotocina $(25 \mathrm{mg} / \mathrm{kg})$. O grupo (C) recebeu uma dieta padrão e uma dose única de tampão citrato. Os animais foram divididos em dois subgrupos: um sedentário (S) e outro exercitado (PE), totalizando quatro grupos: C-S; C-PE; HF-S; HF-PE. A massa corporal e a glicemia capilar foram mensuradas semanalmente. Após a eutanásia, sangue e fígado foram coletados. Concentrações plasmáticas e hepáticas de triacilglicerol, lipoproteína de muito baixa densidade (VLDL); alanina-transaminase (ALT), aspartato-transaminase (AST) e arginase; ureia, lactato e 8-isoprostano (marcador de estresse oxidativo) foram dosadas. Resultados: A glicemia capilar foi maior nos grupos HF-S e HF-PE do que em C-S e C-PE. Não houve diferenças em ALT, AST, arginase e no estresse oxidativo entre os grupos. Ureia foi menor em HF-S e HF-PE do que em C-PE. TAG e VLDL hepáticos foram maiores no grupo HF-PE do que no C-S. Conclusões: O protocolo usado induziu T2DM, mas não doenças hepáticas ou estresse oxidativo. Além disso, o PE agiu em sinergia com a dieta HF induzindo acumulação hepática de TAG e VLDL, um efeito que pode representar lipotoxicidade ou um efeito protetivo para conservação de energia.

Palavras-chave: Dieta rica em gordura. Metabolismo de aminoácidos. Resistência à insulina. Triacilglicerol.

RECEBIDO EM: 12/12/2019

MODIFICAÇÕES SOLICITADAS EM: 6/2/2020

ACEITO EM: 10/7/2020

\footnotetext{
Universidade Federal de Jataí - Instituto de Biociências. Jataí/GO, Brasil.

Detroit R\&D, Inc, 2727, 2nd street, Detroit, MI, 48208 USA. Fairmont State University - Department of Education, Health and Human Performance, Fairmont, WV, USA. 1201 Locust Avenue, Fairmont, WV 26554

3 Autora correspondente. Universidade Federal de Jataí - Instituto de Biociências. Jataí/GO, Brasil. http://lattes.cnpq.br/7352053592004344. https://orcid. org/0000-0002-3741-3787. sandrabenite@gmail.com
} 


\section{INTRODUCTION}

Diabetes is a growing epidemic expected to reach half of billion worldwide subjects (WHO, 2018). Type 2 Diabetes Mellitus (T2DM) accounts for $90-95 \%$ of the de diabetes cases, is a multifactorial disease linked with combined obesity, hyperlipidemia, physical inactivity that leads to the development of insulin resistance (SANTOS et al., 2014). Long periods of hyperglycemia, a common condition of diabetic patients, induces a great number of diabetes complications such as nephropathy, retinopathy, liver diseases and neuropathy (LIU et al., 2017). In 2015, an estimated 1.6 million deaths were directly caused by diabetes and its complications (WHO, 2018).

Liver complications induced by diabetes is a leading cause of death among diabetes population. In fact, the entire spectrum of liver disease is seen in patients with T2DM (LIU et al., 2017). This includes abnormal liver enzymes, nonalcoholic fatty liver disease (NAFLD), cirrhosis, hepatocellular carcinoma, and acute liver failure (LIU et al., 2017). The initial and most important indicators in assessing liver injury are levels of plasma and liver alanine transaminase (ALT), aspartate transaminase (AST), alkaline phosphatase (ALP) and $\gamma$-glutamyl transpeptidase (GGT) (DE CHIARA, et al., 2018; SHAHWAN et al., 2019; YOUNOSSI et al., 2019). Also, insulin resistance contributes to a metabolic deregulation, altering carbohydrate metabolism in liver causing an imbalance between protein synthesis and catabolism, the latter being favored in T2DM due to precursors supply to the gluconeogenic pathway (SADIE; SREEKUMARAN, 2010). Thus, in the development of T2DM, hepatic metabolism of carbohydrate and lipid become dysfunctional, which might favor the catabolism of protein.

The role of oxidative stress has been an important element for the understanding of the complex mechanism by which diabetes and its complications are developed (SANTOS et al., 2011). Using a methodology to induce T2DM in rodents (a single low injection of streptozotocin combined with high fat diet), our previous study demonstrated that 8-isoprostane (a marker for oxidative stress) is increase in skeletal muscle accounting to mitochondrial dysfunction and insulin resistance (SANTOS et al., 2018). The increase of oxidative stress was suggested to also be involved on the underlying mechanism of diabetes that contributes to liver damage (MOHAMED et al., 2016). However, most of the studies carried out with the pur- pose of verifying the effect of diabetes in liver diseases used a protocol to induce Type 1 diabetes mellitus not T2DM.

A great body of the literature well demonstrated that aerobic physical exercises ameliorate the conditions of T2DM patients by improving glucose uptake in skeletal muscle and adiposity decreasing hyperglycemia and hyperlipidemia (BENITE-RIBEIRO et al., 2010; SANTOS et al., 2014) However, the effect of regular exercise on liver diseases induced by T2DM is not well identified. Thus, the first aim of this study was to verify the effect of a T2DM- induced protocol on liver diseases development and its link with oxidative stress. The second aim was to verify the effect of exercise on the potential impact of T2DM on liver diseases.

\section{METHODS}

\section{Ethical aspects}

The experimental protocol was approved by the Ethics Committee on the Use of Animals (CEUA) of Federal University of Goiás according to guidelines and regulations from the National Council for Animal Experimentation Control in Brazil (CONCEA) and registered under number 34, the year 2014. The experimental procedures followed the recommendations of Grundi (2015).

\section{Animals and diet}

Animals of the species Rattus norvegicus were kept in pairs in polypropylene cages $(500 \times 600 \times 220$ $\mathrm{cm}$ ). Cages were sheltered in climate chambers (Insight LTDA, Ribeirão Preto, State of São Paulo, Brazil); inverted light/dark cycle and temperature at $22 \pm 1$ 으. Food and water were offered ad libitum.

Male Wistar rats $(n=46)$ with eight weeks old and an average weight of $236 \mathrm{~g}$ were separated into four groups, depending on the diet type and physical training. The control group $(C, n=23)$ received standard diet for rats $(3868 \mathrm{cal} / \mathrm{kg}, 24.82 \% \mathrm{kcal}$ protein, $63.08 \% \mathrm{kcal}$ carbohydrate and $12.10 \% \mathrm{kcal}$ fat - ${ }^{\circledR}$ PragSoluções, Jaú, State of São Paulo, Brazil) and the T2DM group received high fat diet $(5205 \mathrm{cal} / \mathrm{Kg}$, $19.98 \% \mathrm{kcal}$ protein, $20.37 \% \mathrm{kcal}$ carbohydrate and $59.65 \%$ fat) (HF, $n=23$ ) during all experimental procedures. On day 14 , after 12 hours of fasting, rats of HF group received a single intraperitoneal injection with low dosage of streptozotocin (STZ 25mg / kg body weight) (STZ> 98\%, Sigma-Aldrich, St. Louis, MO, USA) diluted in citrate buffer, $\mathrm{pH} 4.5$ Control group (C), af- 
ter 12 hours of fasting, received an injection of citrate buffer $\mathrm{pH} 4.5$ (Fig 1) This methodology of T2DM induction was validated by Mansor et al. (2013) and successfully tested by our group Santos et al. (2018).

\section{Experimental groups and exercise training}

Animals were them assigned into two subgroups: one sedentary (S) and the other submitted to physical exercise (PE), totalizing four groups: C-S; $\mathrm{C}-\mathrm{PE}$; HF-S; HF-PE. Animals in exercised groups were submitted to a swimming protocol for six weeks, five sessions per week, with an increase in swimming time each week until reaching 55 minutes of swimming (Fig 1). Swimming exercise protocol was adapted from Zacarias et al. (2017). The animals were not familiar with swimming, because of this the protocol started with 30 min of swimming and reached 55 min. Body weight was measured with a Shimadzu balance and capillary glucose was obtained with One Touch ${ }^{\circledR}$ Ultra (São Paulo, State of São Paulo, Brazil), both measured weekly.

\section{Tissues collection}

At the end of the eighth week and after 48 hours of the last PE session, animals were anesthetized with inhaled isoflurane and euthanized. Blood was collected and centrifuged at $1814 \mathrm{~g}$ during 10 minutes at $25^{\circ} \mathrm{C}$. Livers were removed and immediately frozen in liquid nitrogen. Subsequently, livers were homogenized at $4^{\circ} \mathrm{C},[0.02 \mathrm{M}] / 0.01 \mathrm{M}$ phosphate in $1 / 1(\mathrm{v} /$ v) glycerol, $\mathrm{pH} 7.4$ in TRIS buffer, and centrifuged at $20.000 \mathrm{~g}$ for 10 minutes at $4^{\circ} \mathrm{C}$.

\section{Biochemical analyzes}

The activity of hepatic enzymes such as alanine transaminase - ALT (E.C 2.6.1.2) and aspartate aminotransferase - AST (E.C 2.6.1.1) was determined by Labtest ${ }^{\circledR}$ colorimetric kits (Lagoa Santa, State of Minas Gerais, Brazil). The activity of hepatic arginase (E.C. 3.5.3.1) was determined according to Mellerup (1967). Plasma and hepatic concentrations of triacyl-

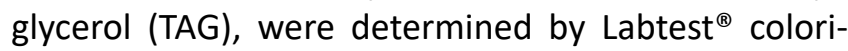
metric kits (Lagoa Santa, State of Minas Gerais, Brazil). Very low-density lipoprotein (VLDL) concentration was determined by the formula: TAG / 5 . Urea and lactate plasma metabolites were determined by Labtest ${ }^{\circledR}$ colorimetric Kits. Oxidative stress was assessed by the concentration of 8-isoprostane in plasma as previous done by us Santos et al. (2018) using ELISA kit (Detroit, $R$ \& D, Inc).

\section{Statistical analyzes}

Data are expressed as mean \pm standard deviation. The outliers were calculated by Grubb's test. The variables presented normal distribution (Shapiro-Wilk test) and were tested by One Way Anova, followed by Tukey. The level of significance stated was $p<0.05$.

\section{RESULTS}

During data exploration, 4 outliers were found, one in each experimental group, which were excluded. Thus, the number of animals in each group was: C-S, $n=10$; C-PE, 11; HF-S, $n=10$; HF- PE, n-11. As shown in our previous study (Santos et al., 2018), the used protocol for T2DM induction in rats was efficient in causing increase in capillary glucose level in animals belonging to the HF-S and HF-PE groups ( $P=0.002)$ as shown in Table 1 . There was not a significant increase in body weight, lactate, plasma TAG and VLDL (Table 1 and Fig $2 A$ and $B$, respectively) and 8-isoprostane (Fig 3) of HF-S and HF-PE group animals when compared to the C-S and C-PE control groups. Plasma urea concentration decreased $(\mathrm{P}=0.002)$ in HF-S and HF-PE when compared to C-PE (Table 1). Besides, hepatic TAG and VLDL were higher in HF-PE compared to C-S ( $P=0.016)$ (Fig $2 C$ and $D$, respectively). No statistical difference was observed in ALT, AST and arginase liver enzyme activity (Table 1 and Fig $2 \mathrm{E}$ and $\mathrm{F}$, respectively).

\section{DISCUSSION}

In this study two hypotheses were tested. The fist hypothesis was that a T2DM - induced protocol using a single dose of STZ together with 8-weeks of high fat food intake could promotes liver diseases via increase in oxidative stress. The second hypothesis was that physical exercise could revert the potential impact of T2DM on liver diseases. To test the first hypothesis, we used a validated T2DM induction protocol (SANTOS et al., 2018) to verify its effect on plasma oxidative stress and hepatic lipid and protein metabolism. Despite of the increase in capillary blood glucose in the diabetes-induced animals (HF), the protocol failed to induce liver diseases or increases blood oxidative stress. However, the T2DM induced protocol seem to affect protein metabolism by altering urea concentration. Also contradicting our hypothesis, the metabolic changes induced by exercise added to the effect of STZ and high fat diet and increased TAG and VLDL in hepatic cells. 
Liver metabolism can be impaired by insulin resistance that could either precedes T2DM establishment or to be induced in consequence of this disease (SHAHWAN et al., 2019). In a cross-sectional study involving 453 T2DM patients, it was observed that $80.8 \%$ presented abnormal hepatic profile parameter (altered ALT and AST), and changes in lipid profiles were associated with abnormal hepatic function (SHAHWAN et al., 2019). Moreover, results of a metanalyses of 80 studies from 20 different countries including 49,419 individuals with T2DM suggested that the overall prevalence of NAFLD is $55.5 \%$ and non-alcoholic steatohepatitis (NASH) is $37.3 \%$ among T2DM population (YOUNOSSI et al., 2019).

The concentration of plasma ALT and AST enzymes are bioindicators of liver damage (SHAHWAN et al., 2019). In fact, studies have reported an increase in hepatic ALT and AST activity when T2DM rats developed NAFLD (SHAHWAN et al., 2019; YOUNOSSI et al., 2019). In an experimental study that analyzed the effect of 12 weeks high fat diet (65\% of fat) intake in rodents, ALT and lipotoxicity was increased (DE CHIARA et al. 2018). In contrast, our T2DM protocol failed to induce changes in hepatic ALT, AST, TAG or VLDL. The reason for the discrepancy could be due the duration of the protocol and the use of STZ to induce T2DM.

Urea is the principal nitrogenous waste product of protein metabolism and is generated from protein breakdown (WATFORD 2003; DE CHIARA et al. 2018). In this study, we observed a decrease in plasma urea levels in the two groups fed with the high-fat diet (HF$S$ and HF-PE) compared to C-PE. One potential explanation for this phenomenon could be that the high-fat diet promoted an increase in fat storage and therefore a saving effect of muscle proteins breakdown. Thus, the results could indicate that the high-fat diet altered the hepatic metabolism (urea cycle) and probably induced by increase in lipid metabolism.

Over several decades epidemiologic studies as well as experimental studies using in-vivo and in-vitro approaches indicated almost unanimously that regular aerobic exercise is a therapeutically approach to control and inhibit T2DM development (BENITE-RIBEIRO et al., 2013; DOS SANTOS et al., 2015; SANTOS et al., 2011). Therefore, the second aim of the study was to investigate the effect of the aerobic exercise on levels of oxidative stress and marker of liver diseases in T2DM. Excessive fat intake could lead to insulin resistance in skeletal muscle and that could be mediated by oxidative as shown by us and others (SANTOS et al., 2018; TANGVARASITTICHAI, 2015). Regular exercise increases the antioxidant capacity and decreases oxidative stress in plasma and other tissues (SIMIONI et al., 2018). Here we observed that the same methodology that induced T2DM and increased oxidative stress in skeletal muscle (SANTOS et al., 2018) failed to affect levels of oxidative stress in plasma even when exercise was performed. In addition, our exercise protocol did not alter oxidative stress in plasma either in the control animals or the group induced for T2DM development.

In present study moderate aerobic exercise did not ameliorate the accumulation of VLDL and TAG, which is associated with liver diseases. In fact, exercise induced a synergistic effect with high fat diet and STZ increasing TAG and VLDL in liver. The mechanism behind this phenomenon might be explained by the increase in gluconeogenesis stimulation, due to metabolic adaptations caused by excess of lipid and by changes in skeletal muscle energy requirement induced by moderate PE. Gluconeogenesis couId have been stimulated by the increase in glycerol concentration on high fat diet, increase in adrenaline induced by exercise and decreased in insulin concentration caused by STZ (BECK-NIELSEN; HOTHER-NIELSEN; STAEHR, 2002; BARTHEL; SCHMOLL, 2003). Altogether, those mechanism seem to exacerbate insulin resistance in hepatic tissues favoring the increase in lipotoxicity observed by the increase in hepatic TAG and VLDL. On the other hand, the increase of TAG and VLDL observed in the HF-PE group could represent a protective mechanism triggered by regular aerobic exercise to conserve fat as energy source since glucose uptake is impaired. However, the exact mechanism behind this outcome waits for further investigation.

\section{CONCLUSION}

In summary, the protocol that induced T2DM, high fat diet and a single injection of STZ, did not induce liver diseases or increase in blood oxidative stress. Besides, PE acted in synergy with high fat diet and STZ inducing accumulation of TAG and VLDL in hepatic tissue, an effect that could either represents lipotoxicity or a protective mechanism to conserve sources of energy. A distinct T2DM- induced protocol, with a longer duration and/or pharmacological approaches might be more suitable to study liver diseases induced by T2DM. 
Table 1 - Effect of T2DM induction protocol and physical exercise on morphological and plasma metabolic changes. Data are expressed as mean \pm standard deviation. C-S $=$ control-sedentary group $(n=10) ; C-P E=$ control-physical exercise group ( $n=11)$; HF-S = high fat diet-sedentary group $(n=10)$; HF-PE high fat diet-physical exercise group $(n=11)$

\begin{tabular}{llllll}
\hline Variables & C-S & C-PE & HF-S & HF-PE & P \\
\hline Body weight $(\mathrm{g})$ & $359.6 \pm 61.9$ & $354.9 \pm 46.3$ & $405.6 \pm 76.1$ & $383.8 \pm 48.7$ & $>0.05$ \\
Capillary glucose $(\mathrm{mmol} / \mathrm{L})$ & $6.7 \pm 0.5$ & $7.0 \pm 0.6$ & $11.4 \pm 4.8^{*}$ & $13.1 \pm 7.6^{*}$ & 0.002 \\
Lactate $(\mathrm{mg} / \mathrm{dL})$ & $15.9 \pm 6.0$ & $14.0 \pm 3.7$ & $18.0 \pm 4.8$ & $14.9 \pm 4.1$ & $>0.05$ \\
Urea $(\mathrm{mg} / \mathrm{dL})$ & $39.4 \pm 10.2$ & $44.9 \pm 8.5^{\#}$ & $32.9 \pm 3.7$ & $34.5 \pm 3.9$ & 0.002 \\
Arginase $(\mu \mathrm{gg} / \mathrm{mg}$.prot) & $0.43 \pm 0.21$ & $0.38 \pm 0.08$ & $0.36 \pm 0.16$ & $0.45 \pm 0.19$ & $>0.05$ \\
\hline
\end{tabular}

Font: The authors.

Figure 1 - Design and timeline of experimental procedures, STZ= streptozotocin, C= Control, $\mathrm{S}=$ sedentary, $\mathrm{PE}=$ Physical exercise training, $\mathrm{HF}=$ High fat diet

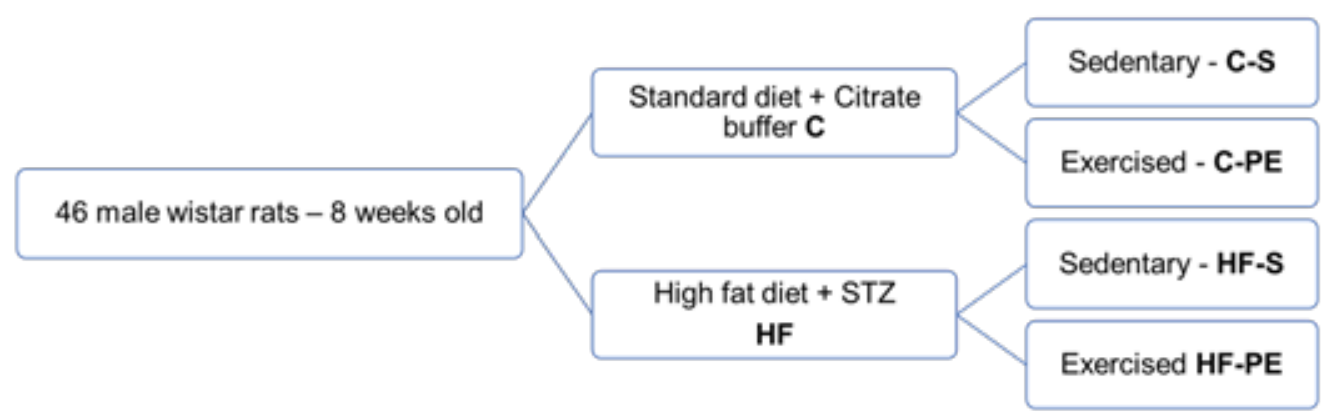

Standard or

High fat diet

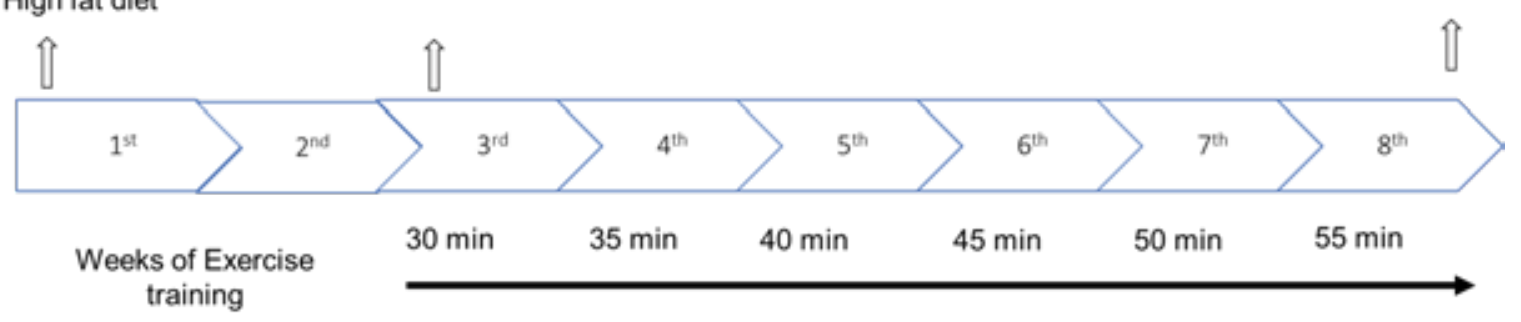

Font: The authors. 
Figure 2 - Effect of T2DM induction protocol and physical exercise on: A- plasma TAG (triacylglycerol) and B- VLDL (very low-density lipoprotein); C- liver TAG and D- VLDL; E- ALT (alanine transaminase) and F- AST (aspartate aminotransferase). Data are expressed as mean \pm standard deviation. $C-S=$ control-sedentary group $(n=10) ; C-P E=$ control-physical exercise group ( $n=11)$; HF-S = high fat diet-sedentary group $(n=10)$; HF-PE high fat diet-physical exercise group $(\mathrm{n}=11) .{ }^{*} \mathrm{p}=0.0016$ HF-PE vs C-S

A

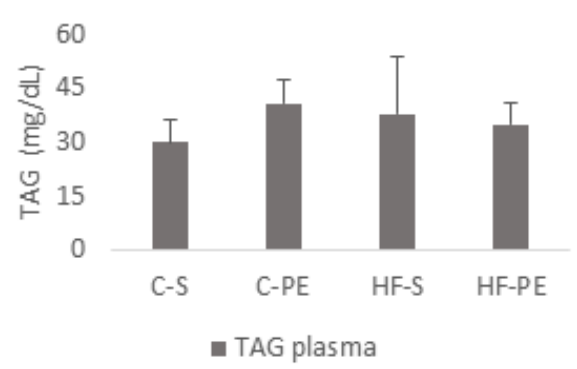

$\mathrm{C}$

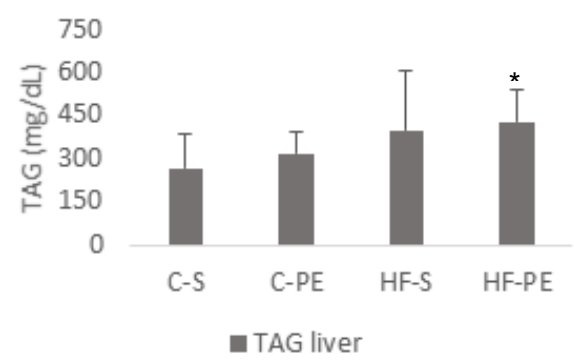

E

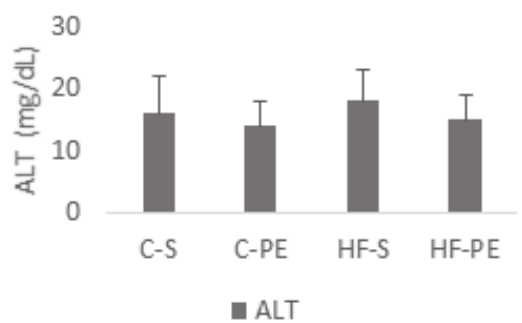

B

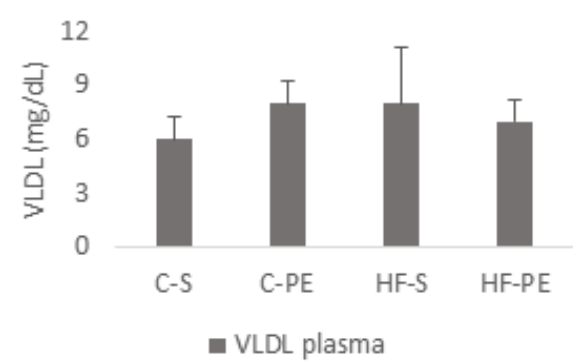

$\mathrm{D}$

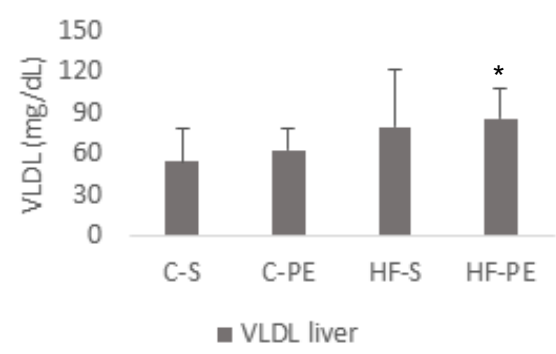

$\mathrm{F}$

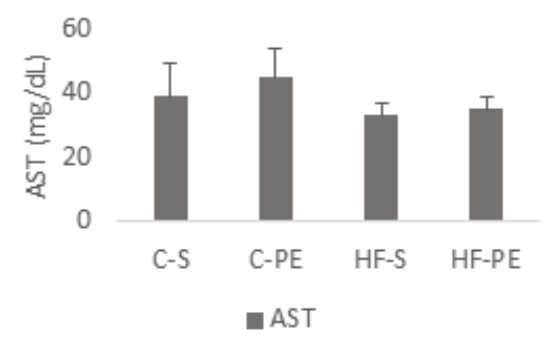

Font: The authors.

Figure 3 - Effect of T2DM induction protocol and physical exercise on plasma 8-isoprostane level. Data are expressed as mean \pm standard deviation. C-S = control-sedentary group ( $n=10)$; C-PE = control-physical exercise group $(n=11) ; H F-S=$ high fat diet-sedentary group $(n=10) ; H F-P E$ high fat diet-physical exercise group $(n=11)$

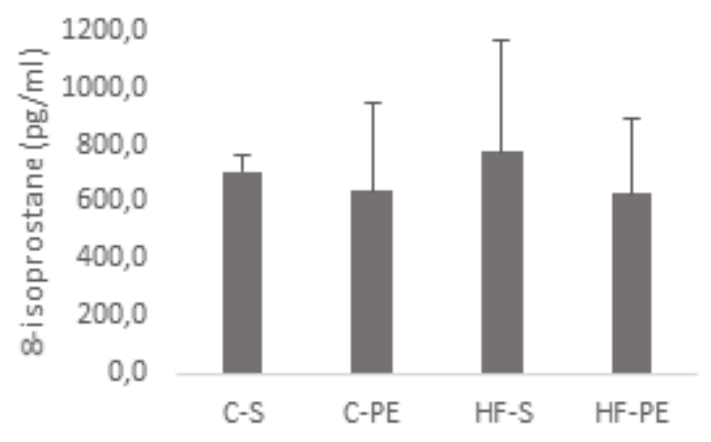

Font: The authors. 


\section{REFERENCES}

BARTHEL, A.; SCHMOLL, D. Novel concepts in insulin regulation of hepatic gluconeogenesis. American Journal of Physiology Endocrinology and Metabolism, v. 285, n. 4, p. 685692, Oct. 2003.

BECK-NIELSEN, H.; HOTHER-NIELSEN, O.; STAEHR, P. Is hepatic glucose production increased in type 2 diabetes mellitus? Current Diabetes Reports, v. 2, n. 3, p. 231-236, May 2002.

BENITE-RIBEIRO, S. A. et al. Influence of regular physical exercise on increased caloric intake triggered by stressors. Annual Review of Biomedical Sciences, v. 2, p. 30-45, Nov. 2010.

BENITE-RIBEIRO, S. A.; SANTOS, J. M.; DUARTE, J. A. R. Moderate physical exercise attenuates the alterations of feeding behaviour induced by social stress in female rats. Cell Biochemistry \& Function, v. 32, n. 2, p. 142-149, June 2013.

DE CHIARA, F. et al. Urea cycle dysregulation in non-alcoholic fatty liver disease. Journal of Hepatology, v. 69, p. 905915, 2018.

DOS SANTOS, J. M. et al. A. The effect of age on glucose uptake and GLUT1 and GLUT4 expression in rat skeletal muscle. Cell Biochemistry \& Function, v. 30, n. 3, p. 191-197, Nov. 2011.

DOS SANTOS, J. M. et al. The effect of exercise on skeletal muscle glucose uptake in type 2 diabetes: An epigenetic perspective. Metabolism Clinical and Experimental, v. 64, n. 12, p. 1.619-1.628, Sept. 2015.

GRUNDI, D. Principles and standards for reporting animal experiments in The Journal of Grundy, D. Principles and standards for reporting animal experiments in The Journal of Physiology and Experimental Physiology, v. 100. p. 755758, June 2015.

LIU, H. et al. Body mass index and mortality in patients with type 2 diabetes mellitus: A prospective cohort study of 11.449 participants. Journal of Diabetes and its Complications, v. 31, n. 2, p. 328-333, Feb. 2017.

MANSOR, L. S. et al. Cardiac metabolism in a new rat model of type 2 diabetes using high-fat diet with low dose streptozotocin. Cardiovascular Diabetology, v. 12, n. 1, p. 136-146, Sept. 2013.

MELLERUP, B. Colorimetric method for rapid determination of serum arginase. Clinical Chemistry, v. 13, n. 10, p. 900908, Oct. 1967.

MOHAMED, J. et al. Mechanisms of Diabetes-Induced Liver Damage: The role of oxidative stress and inflammation. Sultan Qaboos University Medical Journal, v. 16, n. 2, p. 132 141, Mayo 2016.

SADIE, L. H.; SREEKUMARAN, N. Protein and energy metabolism in type 1 diabetes. Clinical Nutrition, v. 29, n. 1, p. 3-17, Feb. 2010.

SANTOS, J. M. et al. The role of mitochondrial DNA damage at skeletal muscle oxidative stress on the development of type 2 diabetes. Molecular and Cellular Biochemistry, v. 449, n. 1-2, p. 251-255, Apr. 2018.
SANTOS, J. M. et al. The interrelation between aPKC and glucose uptake in the skeletal muscle during contraction and insulin stimulation. Cell Biochemistry \& Function, v. 32, n. 8, p. 621-624, Dec. 2014.

SANTOS, J. M. et al. Diabetic retinopathy, superoxide damage and antioxidants. Current Pharmaceutical Biotechnology, v. 12, n. 3, p. 352-361, Mar. 2011.

SHAHWAN, M. J. et al. Association between abnormal serum hepatic enzymes, lipid levels and glycemic control in patients with type 2 diabetes mellitus. Obesity Medicine, v. 16, Dec. 2019.

SIMIONI, C. et al. Oxidative stress: role of physical exercise and antioxidant nutraceuticals in adulthood and aging. Oncotarget, 9(24), p. 17.181-17.198, 2018. https://doi. org/10.18632/oncotarget.24729

TANGVARASITTICHAI, S. Oxidative stress, insulin resistance, dyslipidemia and type 2 diabetes mellitus. World Journal of Diabetes, v. 6, n. 3, p. 456-480, Apr. 2015.

WATFORD, M. The urea cycle: Teaching intermediary metabolism in a physiological setting. Biochem Mol Biol Educ; 31, 5, p. 289-97, 2003.

WHO. World Health Organization. Diabetes. Disponível em: http://www.who.int/en/news-room/fact-sheets/detail/diabetes. Acesso em: 12 June 2018.

ZACARIAS, A. C. et al. Swimming training induces liver mitochondrial adaptations to oxidative stress and insulin sensitivity in rats submitted to high-fat diet. Redox Report: Communications in Free Radical Research, v. 22, n. 6, p. 515-523, Apr. 2017.

YOUNOSSI, Z. M. et al. The global epidemiology of NAFLD and NASH in patients with type 2 diabetes: A systematic review and meta-analysis. Journal of Hepatology, v. 71, p. 793-801, 2019. 